\title{
PENETAPAN KADAR FLAVONOID TOTAL EKSTRAK ETANOL KULIT BUAH ALPUKAT (Persea americana Mill.) DENGAN METODE SPEKTROFOTOMETRI UV-VIS
}

\author{
Aminah ${ }^{1}$, Nurhayati Tomayahu, Zainal Abidin \\ Fakultas Farmasi, Universitas Muslim Indonesia \\ 1aminah.aminah@umi.ac.id
}

\begin{abstract}
Avocado plant (Persea americana Mill.), belongs to Lauraceae family which have medicinal properties. Avocado peel contains flavonoid compounds that can be used to protect and reduce the skin damage against UV rays. This study aimed to determine the total flavonoids content of the ethanol extract of the avocado peel using UV-Vis spectrophotometry. The ethanol extract of avocado peel was obtained by maceration with ethanol. The qualitative analysis used $\mathrm{FeCl}_{3}$ by forming green complex. The determination of total flavonoids content is conducted based on $\mathrm{AlCl}_{3}$ method with total flavonoids expressed in QE (Quercetin equivalent) at the maximum wavelength of $435 \mathrm{~nm}$. The result showed that the average content of flavonoid total is $4.0122 \mathrm{mgQE} / \mathrm{g}$ extract.
\end{abstract}

Keywords: Flavonoid Total, Caucasian avocado (Persea americana Mill.), UV-Vis spectrophotometry

\section{PENDAhuluan}

Indonesia merupakan negara yang memiliki kekayaan alam dengan berbagai jenis tanaman yang dapat berkhasiat sebagai obat tradisional. Obat tradisional semakin banyak diminati oleh masyarakat karena bahan nabatinya mudah didapat, mudah diracik dan harganya terjangkau, sehingga bahan yang digunakan harus ditingkatkan mutu dan kualitasnya sesuai dengan kebutuhan masyarakat.

Salah satu tumbuhan yang menarik untuk diteliti adalah buah alpukat dari family Lauraceae yang merupakan tanaman yang dapat berkhasiat sebagai obat, tanaman ini dapat tumbuh di daerah tropis dan subtropis (Katja, Suryanto \& Wehantouw 2009, h. 58).

Alpukat secara empiris berkhasiat mengobati penyakit seperti sariawan, kencing batu, sakit gigi, muka kering, bengkak karena peradangan dan juga kencing manis (Katja, Suryanto \& Wehantouw 2009, h. 58). Kulit alpukat mengandung senyawa flavonoid yang dapat digunakan untuk melindungi kulit terhadap sinar UV atau mampu mengurangi kerusakan kulit, karena senyawa ini bekerja sebagai bahan aktif tabir surya (Mokodompit, Edy dan Wiyono 2013, h. 85).

Flavonoid merupakan salah satu senyawa golongan fenol alam terbesar yang terdapat dalam semua tumbuhan hijau (Markham, K.R 1988). Menurut (Pourmorad, F 2006, h. 1143) mengemukkan bahwa salah satu golongan senyawa polifenol ini diketahui memiliki sifat sebagai penangkap radikal bebas, penghambat enzim hidrolisis, oksidatif, dan juga bekerja sebagai antiinflamasi.

Berdasarkan uraian tersebut, maka perlu dilakukan penelitian yang lebih intensif mengenai pengujian kadar flavonoid total dari ekstrak etanol kulit buah alpukat (Persea americana Mill.), sehingga potensi tumbuhan ini sebagai bahan baku obat untuk pencegahan maupun pengobatan berbagai penyakit dapat lebih dikembangkan dengan maksimal.

\section{METODE PENELITIAN}

\section{A. Pengambilan dan Pengolahan Sampel}

Pengambilan Sampel buah alpukat (Persea americana Mill.) dilakukan pada pagi hari sekitar pukul 10.00 WITA di Malino, Sulawesi selatan. Kemudian disortasi basah untuk menghilangkan tanah dan pengotor lainnya yang masih menempel pada sampel. Kemudian buah alpukat dipisahkan dari daging buah dan kulit buahnya lalu di bersihkan. Kulit buah alpukat (Persea americana Mill.) yang telah dibersihkan dilakukan pengubahan bentuk dengan cara dipotong-potong kecil, selanjutnya dikeringkan dengan cara diangin-anginkan selama beberapa hari pada udara terbuka dengan tidak terkena sinar matahari langsung. Setelah kering sampel ditimbang dan dicatat berat keringnya kemudian diserbukkan setelah itu ditimbang kembali berat sampel serbuk yang di peroleh (Dahlia \& Ahmad 2016, h. 16).

\section{B. Proses ekstraksi kulit alpukat (Persea americana Mill.)}

Sebanyak 50 gram sampel kulit buah alpukat (Persea americana Mill.) dimasukkan kedalam wadah maserasi. Kemudian ditambahkan dengan etanol 96\% $200 \mathrm{~mL}$ sampai seluruh sampel terendam, kemudian ditutup dan dibiarkan selama 24 jam. Maserat disaring dengan menggunakan kertas saring. Filtrat diperoleh melalui penyaringan dengan corong, kemudian ampas dimaserasi kembali dengan etanol 96\% $200 \mathrm{~mL}$, sehingga filtrat hampir tidak berwarna. 
Semua filtrat disatukan dan dipekatkan dengan menggunakan rotavapor sampai tidak ada lagi cairan yang menetes sehingga diperoleh ekstrak etanol kulit buah alpukat (Persea americana Mill.). Ekstrak kental kulit buah alpukat (Persea americana Mill.) yang didapatkan digunakan untuk dianalisis lebih lanjut (Gustandy, M dan Soegihardjo, C,J 2016).

\section{Analisis Kuantitatif Kandungan Flavonoid}

Sebanyak $1 \mathrm{mg}$ ekstrak etanol kulit buah alpukat (Persea americana Mill.) ditambahkan dengan 2 tetes $\mathrm{FeCl}_{3}$. Terbentuknya warna hijau atau hijau biru menunjukkan adanya senyawa flavonoid dalam bahan (Harborne, J.B 1987).

\section{Analisis Kualitatif Kandungan Flavonoid \\ 1. Penentuan panjang gelombang maksimum ( $\left.\chi_{\text {maks }}\right)$ kuersetin}

Penentuan panjang gelombang maksimum kuersetin dilakukan dengan running larutan kuersetin pada range panjang gelombang $400-450 \mathrm{~nm}$. Hasil running menunjukkan panjang gelombang maksimum standar baku kuarsetin berada pada panjang gelombang $435 \mathrm{~nm}$. Panjang gelombang maksimum tersebut yang digunakan untuk mengukur serapan dari sampel ekstrak etanol kulit buah alpukat (Persea americana Mill.).

\section{Pembuatan kurva standar kuarsetin}

Ditimbang sebanyak $25 \mathrm{mg}$ baku standar kuersetin dan dilarutkan dalam $25 \mathrm{~mL}$ etanol. Larutan stok dipipet sebayak $1 \mathrm{~mL}$ dan dicukupkan volumenya sampai $10 \mathrm{~mL}$ dengan etanol sehingga diperoleh konsentrasi 100 ppm. Dari larutan standar kuersetin 100 ppm, kemudian dibuat beberapa konsentrasi yaitu 6 ppm, 8 ppm, 10 ppm, 12 ppm dan 14 ppm. Dari masing-masing konsentrasi larutan standar kuersetin dipipet $1 \mathrm{~mL}$. Kemudian ditambahkan $1 \mathrm{~mL} \mathrm{AlCl}{ }_{3} 2 \%$ dan $1 \mathrm{~mL}$ kalium asetat $120 \mathrm{mM}$. Sampel diinkubasi selama satu jam pada suhu kamar. Absorbansi ditentukan menggunakan metode spektrofotometri $\mathrm{UV}-\mathrm{Vis}$ pada panjang gelombang maksimum $435 \mathrm{~nm}$ (Stankovic, M.S., 2011, h. 65).

\section{Penetapan kadar flavonoid total ekstrak etanol kulit buah alpukat (Persea americana Mill.)}

Ditimbang $15 \mathrm{mg}$ ekstrak, dilarutkan dalam $10 \mathrm{~mL}$ etanol, sehingga diperoleh konsentrasi 1500 ppm. Dari larutan tersebut dipipet $1 \mathrm{~mL}$ kemudian ditambahkan $1 \mathrm{~mL}$ larutan $\mathrm{AlCl}_{3} 2 \%$ dan $1 \mathrm{~mL}$ kalium asetat $120 \mathrm{mM}$. Sampel diinkubasi selama satu jam pada suhu kamar. Absorbansi ditentukan menggunakan metode spektrofotometri UV-Vis pada panjang gelombang maksimum $435 \mathrm{~nm}$. Sampel dibuat dalam tiga replikasi untuk setiap analisis dan diperoleh nilai rata-rata absorbansi (Stankovic, M.S., 2011, h. 65).

\section{HASIL DAN PEMBAHASAN}

Tumbuhan alpukat (Persea americana Mill.) yang digunakan dalam penelitian ini yaitu hanya pada bagian kulit buahnya. Kulit buah alpukat (Persea americana Mill.) dapat digunakan sebagai bahan aktif tabir surya yaitu untuk melindungi kulit terhadap sinar UV atau mampu mengurangi kerusakan kulit, karena mengandung senyawa flavonoid (Mokodompit, Edy dan Wiyono 2013, h. 85).

Flavonoid hampir terdapat pada semua bagian tumbuhan termasuk buah, akar, daun, dan kulit luar batang. Flavonoid merupakan senyawa alam yang berpotensi sebagai antioksidan yang dapat menangkal radikal bebas yang berperan pada timbulnya penyakit degeneratif melalui mekanisme perusakan sistem imunitas tubuh, oksidasi lipid dan protein (Rais, I.R 2015, h. 103).

Pada penelitian ini buah alpukat yang digunakan diperoleh dari Malino, Sulawesi selatan. Kotoran ataupun serangga yang menempel pada buah alpukat harus dibersihkan karena dapat mengganggu proses dan hasil ekstraksi. Kulit buah alpukat (Persea americana Mill.) dilakukan pengubahan bentuk dengan cara dipotong-potong kecil untuk mempercepat proses pengeringan. Proses pengeringan ini dimaksudkan untuk mengurangi kadar air yang terdapat pada sampel, sehingga dapat mencegah pembusukan oleh bakteri.

Proses ekstraksi dilakukan bertujuan untuk mengambil senyawa kimia yang terkandung dalam sampel. Prinsip ekstraksi didasarkan pada perpindahan masa komponen zat yang terlarut ke dalam pelarut sehingga terjadi perpindahan pada lapisan antar muka dan berdifusi masuk ke dalam pelarut (Harborne, J.B 1987). Pelarut yang digunakan pada penelitian ini adalah etanol $96 \%$ sebagai pelarut polar. Dalam hal penyarian, etanol memiliki kelebihan dibandingkan dengan air dan metanol. Senyawa kimia yang mampu disari dengan etanol lebih banyak dari pada penyari metanol dan air (Azizah dan Salamah 2013, h. 24).

Untuk mendapatkan senyawa kimia yang diinginkan digunakan metode ekstraksi yang merupakan metode penyarian zat berkhasiat atau zat aktif dari bagian tanaman dengan menggunakan pelarut yang sesuai (Yuliani \& Satuhu, 2012).

Metode ekstraksi yang digunakan pada penelitian ini adalah maserasi, karena metode ini lebih sederhana, mudah dan tanpa pemanasan. Karena jika menggunakan pemanasan dapat membuat kadar flavonoid berkurang. Proses maserasi menggunakan 3 replikasi dengan etanol 96\% $200 \mathrm{~mL}$ selama 24 jam. Penambahan pelarut etanol dilakukan sampai 3 kali proses ekstraksi. 
Ekstrak yang diperoleh dipekatkan dengan rotavapor sampai diperoleh ekstrak kental yang berwarna hijau tua. Kemudian dilakukan perhitungan rendamen, sehingga diperoleh rata-rata persen rendamen yaitu $17,28 \%$. Penentuan rendamen ini berfungsi untuk mengetahui kadar metabolit sekunder yang terbawa oleh pelarut namun tidak dapat menentukan jenis senyawa yang terbawa oleh pelarut (Ahmad, Juwita dan Malik 2016, h. 6). Dapat dilihat pada tabel 1.

Tabel 1. Hasil ekstrak etanol dari kulit buah alpukat (Persea americana Mill.)

\begin{tabular}{cccccc|}
\hline $\begin{array}{c}\text { Jenis } \\
\text { pelarut }\end{array}$ & $\begin{array}{c}\text { Volume Berat } \\
\text { pelarut }\end{array}$ & $\begin{array}{c}\text { Berat } \\
\text { sampel(g) }\end{array}$ & $\begin{array}{c}\text { ekstrak(g) } \\
\text { rendamen rendamen }\end{array}$ \\
\hline Etanol & $200 \mathrm{~mL}$ & 50 & 8,9689 & 17,9378 & \\
$96 \%$ & $200 \mathrm{~mL}$ & 50 & 8,5552 & 17,1104 & 17,28 \\
& $200 \mathrm{~mL}$ & 50 & 8,3959 & 16,7918 & \\
\hline
\end{tabular}

Analisis kualitatif dilakukan untuk mengetahui komponen kimia pada tumbuhan dengan menggunakan reagen besi (III) klorida $\left(\mathrm{FeCl}_{3}\right)$. Diamati perubahan warna yang terbentuk yaitu warna hijau (Harborne, J.B 1987). Hasil identifikasi menunjukkan ekstrak etanol kulit buah alpukat (Persea americana Mill.) positif mengandung flavonoid yang dapat dilihat pada tabel 2 .

Tabel 2. Hasil analisis kualitatif ekstrak etanol kulit buah alpukat (Persea americana Mill.)

\begin{tabular}{cccc}
\hline Sampel & Pereaksi & Warna & Ket \\
\hline $\begin{array}{l}\text { Ekstrak etanol kulit } \\
\text { buah alpukat (Persea } \\
\text { americana Mill.) }\end{array}$ & $\mathrm{FeCl}_{3}$ & Hijau & $(+)$ \\
& & & \\
\end{tabular}

Analisis kuantitatif senyawa flavonoid total dengan menggunakan spektrofotometri UV-Vis dilakukan untuk mengetahui seberapa besar kadar flavonoid total yang terkandung pada ekstrak etanol kulit buah alpukat (Persea americana Mill.). Analisis flavonoid dilakukan dengan menggunakan Spektrofotometri UV-Vis karena flavonoid mengandung sistem aromatik yang terkonjugasi sehingga menunjukkan pita serapan kuat pada daerah spektrum sinar ultraviolet dan spektrum sinar tampak (Harborne, J.B 1987).

Pada penelitian ini untuk menentukan kadar flavonoid total pada sampel digunakan kuarsetin sebagai larutan standar dengan deret konsentrasi 6, 8, 10, 12 dan 14 ppm. Digunakan deret konsentrasi karena metode yang di pakai dalam menentukan kadar adalah metode yang menggunakan persamaan kurva baku, untuk membuat kurva baku terlebih dahulu dibuat beberapa deret konsentrasi untuk mendapatkan persamaan linear yang dapat digunakan untuk menghitung persen kadar. Digunakan kuarsetin sebagai larutan standar karena kuersetin merupakan flavonoid golongan flavonol yang mempunyai gugus keto pada C-4 dan memiliki gugus hidroksil pada atom C-3 atau C-5 yang bertetangga dari flavon dan flavonol (Azizah dan Faramayuda 2014, h. 48). Pengukuran serapan panjang gelombang maksimum dilakukan running dari panjang gelombang $400-450$ $\mathrm{nm}$. Hasil running menunjukkan panjang gelombang maksimum standar baku kuarsetin berada pada panjang gelombang $435 \mathrm{~nm}$. Panjang gelombang maksimum tersebut yang digunakan untuk mengukur serapan dari sampel ekstrak etanol kulit buah alpukat (Persea americana Mill.). Dapat dilihat pada tabel 3.

Tabel 3. Hasil pengukuran absorbansi larutan standar kuersetin pada panjang gelombang maksimum 435 nm

\begin{tabular}{cc}
\hline Konsentrasi $(\mathrm{ppm})$ & Absorbansi $(\mathrm{y})$ \\
\hline 6 & 0,278 \\
8 & 0,378 \\
10 & 0,442 \\
12 & 0,555 \\
14 & 0,628 \\
\hline
\end{tabular}

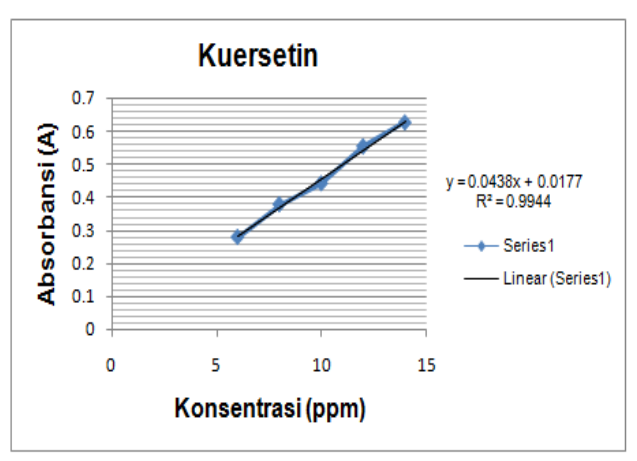

Gambar 1. Kurva kalibrasi kuersetin pada panjang gelombang maksimum $435 \mathrm{~nm}$

Dari pengukuran tersebut, dapat disimpulkan bahwa semakin tinggi konsentrasi yang digunakan maka semakin tinggi pula absorban yang di peroleh. Hasil baku kuersetin yang diperoleh diplotkan antara kadar dan absorbannya, sehingga diperoleh persamaan regresi linear yaitu $y=0,0438 x+0,0177$ dengan nilai $\mathrm{R}^{2}$ yang diperoleh sebesar 0,9944 dan nilai $\mathrm{r}$ adalah 0,997. Persamaan kurva kalibrasi kuersetin dapat digunakan sebagai pembanding untuk menentukan konsentrasi senyawa flavonoid total pada ekstrak sampel.

Pengujian analisis kuantitatif dengan spektrofotometri UV-Vis digunakan larutan blanko 
sebagai kontrol yang berfungsi sebagai pemblank (mengkali nol-kan) senyawa yang tidak perlu dianalisis (Basset, 1994).

Pada pengukuran senyawa flavonoid total, larutan sampel ditambahkan $\mathrm{AlCl}_{3}$ yang dapat membentuk kompleks, sehingga terjadi pergeseran panjang gelombang ke arah visible (tampak) yang ditandai dengan larutan menghasilkan warna yang lebih kuning. Dan penambahan kalium asetat yang bertujuan untuk mempertahankan panjang gelombang pada daerah visible (tampak) (Chang et al, 2002). Perlakuan inkubasi selama 1 jam sebelum pengukuran dimaksudkan agar reaksi berjalan sempurna, sehingga intensitas warna yang dihasilkan lebih maksimal (Azizah dan Faramayuda 2014, h. 48). Sehingga dari hasil penelitian ini diperoleh kadar flavonoid total ekstrak etanol kulit buah alpukat (Persea americana Mill.) sebesar 4,0122 mgQE/g ekstrak yang dapat dilihat pada tabel 3 .

Tabel 4. Hasil penetapan kadar flavonoid total \% (b/b) pada ekstrak etanol kulit buah alpukat (Persea americana Mill.)

\begin{tabular}{ccccc}
\hline & $\begin{array}{c}\text { Abs } \\
\text { Replikasi }\end{array}$ & $\begin{array}{c}\text { Kandungan } \\
\text { flavonoid } \\
\text { total awal } \\
(\mathrm{mg} / \mathrm{L})\end{array}$ & $\begin{array}{c}\text { Kandungan } \\
\text { total } \\
\text { flavonoid } \\
\text { (mgQE/g } \\
\text { ekstrak) }\end{array}$ & $\begin{array}{c}\text { Rata-rata } \\
\text { kandungan } \\
\text { flavonoid } \\
\text { total } \\
\text { (mgQE/g) }\end{array}$ \\
\hline 1 & 0,291 & 6,2397 & 4,1050 & \\
2 & 0,276 & 5,8972 & 3,9054 & 4,0122 \\
3 & 0,284 & 6,0799 & 4,0264 & \\
\hline
\end{tabular}

Menurut penelitian yang telah dilakukan oleh kurniasari (2006) menyatakan bahwa sejumlah tanaman obat yang mengandung flavonoid telah dilaporkan memiliki aktivitas antioksidan, antibakteri, antivirus, antiradang, antialergi dan antikanker.

\section{KESIMPULAN}

Berdasarkan hasil penelitian yang telah dilakukan dapat disimpulkan bahwa kadar flovonoid total dari ekstrak etanol kulit buah alpukat (Persea americana Mill.) yaitu 4,0122 mgQE/g ekstrak.

\section{DAFTAR PUSTAKA}

Ahmad, A.R., Juwita, J., Ratulangi, S.A.D. dan Malik, A., 2016. Penetapan Kadar Fenolik Dan Flavonoid Total Ekstrak Metanol Buah Dan Daun Patikala (Etlingera Elatior (Jack) Rm Sm) Menggunakan Spektrofotometri UvVis. Pharmaceutical Sciences And Research (Psr), 2(1), Pp.1-10.

Azizah, B. dan Salamah, N., 2013. Standarisasi Parameter Non Spesifik dan Perbandingan Kadar Kurkumin Ekstrak Etanol dan Ekstrak
Terpurifikasi Rimpang Kunyit. Pharmaciana, 3(1).

Azizah, D.N. dan Faramayuda, F., 2014. Penetapan Kadar Flavonoid Metode $\mathrm{AlCl}_{3}$ Pada Ekstrak Metanol Kulit Buah Kakao (Theobroma Cacao L.). Kartika Jurnal Ilmiah Farmasi, 2(2).

Basset, J., R. C. Denney, G.H Jeffrey, J. Mendhom., 1994. Buku Ajar Vogel Kimia Analisis Kuantitatif Anorganik, Jakarta : EGC.

Chang C. Yang M, Wen Hand Chern J. 2002. Estimation of Total Flavonoid Content in Propolis by Two Complementary Colorimetric Methods, J. Food Drug Anal.

Dahlia, A.A. dan Ahmad, A.R., 2016. Penetapan Kadar Flavonoid Total Dari Ekstrak Etanolik Daun Benalu Mangga (Dendrophthoe Pentandra L. Miq). Jurnal Fitofarmaka Indonesia, 1(1). pp.14-17.

Gustandy, M, dan Soegihardjo, C,J 2016, 'Uji Aktivitas Antioksidan Menggunakan Radikal 1, 1-Difenil-2-Pikrihidrazil dan Penetapan Kandungan Fenolik Total Fraksi Etil Asetat Ekstrak Etanol Buah Anggur Bali (Vitis vinifera L.)', Jurnal Farmasi Sains dan Komunitas, 10(2).

Harborne, J.B., 1987, Metode Fitokimia; Penuntun Cara Modern Menganalisa Tumbuhan, Terbitan Kedua, Terjemahan Kosasih Padmawinata dan Iwang Soediro ITB, Bandung.

Katja, D. G., Suryanto, E., dan Wehantouw, F., 2009. Potensi daun alpukat (persea Americana Mill.) sebagai sumber antioksidan alami. Chemistry Progress, 2(1), pp. 58-64.

Kurniasari, I. 2006. Metode cepat penentuan flavanoid total meniran (Phyllantus niruri L) berbasis teknik spektrofotometri inframerah dan kemometrik. Bogor: IPB

Markham, K.R. 1988. Cara Mengidentifikasi Flavonoid. Penerjemah Kosasih Padmawinata.Bandung: ITB.

Mokodompit, AN, Edy, HJ dan Wiyono, W 2013, Penentuan nilai sun protective factor (spf) secara in vitro krim tabir surya ekstrak etanol kulit alpukat. Pharmacon, 2(3), pp. 83-85.

Pourmorad, F., Hosseinimehr, S.J. and Shahabimajd, N., 2006. Antioxidant activity, phenol and flavonoid contents of some selected Iranian medicinal plants. African journal of biotechnology, 5(11). pp 1142-1145

Rais, I. R., 2015. Isolasi dan penentuan kadar flavonoid ekstrak etanolik herba sambiloto (andrographis paniculata (burm. F.) Ness). Pharmaciana, pp 100:106.

Stankovic, M.S., 2011. Total phenolic content, 
flavonoid concentration and antioxidant activity of Marrubium peregrinum L. extracts. Kragujevac J Sci, 33(2011), pp.6372.

Yuliani, S. dan Satuhu, S., 2012. Panduan lengkap minyak atsiri. Penebar swadaya: Jakarta. Hal, 46. 